\title{
Long-term outcome in children with nutritional vitamin B12 deficiency
}

\author{
Nutrisyonel vitamin B12 eksikliği olan çocuklarda uzun dönem sonuçlar
}

\author{
Melike Sezgin Evim ${ }^{1}$, Şahin Erdöl${ }^{2}$, Özlem Özdemir ${ }^{3}$, Birol Baytan¹, Adalet Meral Güneş ${ }^{1}$ \\ 'Department of Pediatric Hematology, Faculty of Medicine, Uludağ University, Bursa, Turkey \\ ${ }^{2}$ Department of Pediatrics, Faculty of Medicine, Uludağ University, Bursa, Turkey \\ ${ }^{3}$ Department of Pediatric Neurology, Faculty of Medicine, Uludağ University, Bursa, Turkey
}

\begin{abstract}
Objective: Vitamin B12 deficiency is frequently observed in developing countries. Herein we report the long-term clinical and laboratory outcomes in $\mathbf{4 5}$ children presented with various symptoms of vitamin B12 deficiency.

Materials and Methods: Symptoms and physical findings, and percentiles for weight, height, and head circumference at presentation were recorded. The educational level of the patients' mothers, vitamin B12 deficiency-related diseases and family income data were collected. Complete blood count, serum vitamin B12, folate, iron, iron binding capacity and ferritin, and plasma homocysteine levels were recorded measured at presentation. The patients were treated with vitamin B12, as follows: $1 \mathrm{mg} / \mathrm{d} I M$ for 1 week, followed by $1 \mathrm{mg}$ IM QWK for 2 weeks, and then monthly $1 \mathrm{mg}$ injections. Patients were neurologically and hematologically re-evaluated after treatment. The visual evoked potential (VEP) test was used to examine the integrity and function of the visual pathway. Brainstem evoked potential (BAEP) responses were used to analyze auditory function. Neuromotor development was assessed using Denver II Development Screening Test.

Results: The mean age of 20 male and 25 female patients was $5.6 \pm 5.9$ years (range: 1.4 months- 17 years). The most common symptoms at presentation were weakness, failure to thrive, and hematologic manifestations (pallor, petechiae, ecchymosis). Abnormal neurologic findings at presentation were observed in $20 \%$ of the patients, and were more commonly observed in those $<2$ years. VEP, BAEP, and Denver II Development tests were performed in $66 \%$ of the patients one year after vitamin B12 replacement was started. VEP and BAEP interval prolongation was observed in $37 \%$ and $17 \%$ of the cases, respectively. Denver II Development Test results showed developmental delay in $20 \%$ of the patients tested.

Conclusion: All the patients achieved full hematologic recovery within 1 month of treatment onset. Neurological symptoms resolved following B12 administration; however, during long-term follow-up ranged from $17 \%$ to $37 \%$ of the tested patients had persistent VEP; BERA, and Denver II abnormalities. Neurological symptoms resolved following B12 administration; however, during long-term followup 33\% of the patients had persistent VEP, BERA, and Denver II abnormalities. As such, clinicians should continue to follow-up such patients even after hematologic and clinical improvement are obtained in order to assess their neurologic status. (Turk J Hematol 2011; 28: 286-93)
\end{abstract}

Key words: Vitamin B12 deficiency, children, neurologic outcome

Received: October 23, 2010

Accepted: May 17, 2011

Address for Correspondence: M.D. Melike Sezgin Evim, Department of Pediatric Hematology, Faculty of Medicine, Uludağ University, Bursa, Turkey Phone: +90 2242950547 E-mail: melikevim@yahoo.com

doi:10.5152/tjh.2011.82 


\title{
Özet
}

\begin{abstract}
Amaç: Vitamin B12 eksikliği gelişmekte olan ülkelerde sık görülür. B12 eksikliğinin değişik yakınmaları ile gelen 45 çocuğun uzun dönem laboratuar ve klinik bulgularını bildirdik.

Yöntemler ve Gereçler: Başvuru anındaki yakınma ve muayene bulguları, kilo, boy ve bas cevresi persentilleri not edildi. Annenin eğitim düzeyi, eşlik eden hastalıklar ve aile geliri sorgulandı. Tanıdaki tam kan sayımı, serum vitamin B12, folat, demir, demir bağlama kapasitesi, ferritin ve plazma homosistein seviyeleri kaydedildi. Tedavi için B12 intramüsküler olarak ilk hafta her gün, sonra iki hafta boyunca haftada bir, takiben aylık verildi. Tedaviden sonra hastalar nörolojik ve hematolojik bulgular için tekrar değerlendirildi. Görsel uyarılmış potansiyel (VEP), görsel yolların fonksiyonlarını ve bütünlüğünü değerlendirmede kullanıldı. Beyin sapı uyarılmış işitsel cevapları (BAEP), işitsel fonksiyonları değerlendirmek için kullanıld, Nöromotor gelişim, Denver II gelişim tarama testi ile değerlendirildi. Bulgular: Ortalama yaş ve cinsiyet oranı sırasıyla 5.6 55.9 yl (1.4 ay -17 yl), 20 erkek/25 kız idi. En sık yakınmalar halsizlik, gelişme geriliği ve hematolojik yakınmalardı. Baş vuruda anormal nörolojik bulgular tüm vakaların \%20'sinde görüldü. Bu bulgular iki yaştan küçük çocuklarda daha sıktı. B12 tedavisinden bir yll sonra VEP, BERA ve Denver II gelişim testi vakaların \%66'sına yapıld. VEP ve BERA'da uzama sırasıyla vakaların \%37 ve \%17'sinde gösterildi. Denver II gelişim testi \%20 hastada gecikmiş bulundu.

Sonuç: Tüm çocuklarda birinci ayda tam hematolojik düzelme sağlandı. Baş vuruda nörolojik bulgular iki yas altında daha sık görüldü. Bu bulgular B12 tedavisi ile geriledi. Buna karşın uzun dönem sonuçlarda VEP, BERA ve Denver II testinde bozukluk test yapılan olguların \%17'si ile \%37'si arasında değişen oranda devam ediyordu. Bu nedenle klinisyenler bu çocukları hematolojik ve klinik düzelme olsa bile nörolojik prognoz açısından uzun vadeli izlemeli ve değerlendirmelidir. (Turk J Hematol 2011; 28: 286-93) Anahtar kelimeler: Vitamin B12 eksikliği, çocuk, nörolojik sonuçlar
\end{abstract}

Kabul tarihi: 17 Mayıs 2011

\section{Introduction}

Vitamin B12 deficiency is usually observed in developing countries and poor dietary intake is the most frequent cause. Vitamin B12 is important for DNA synthesis and neurologic functions. The vitamin B12 deficiency negatively affects bone marrow, gastrointestinal and central nervous systems [1,2]. Most children with vitamin B12 deficiency present with non-specific manifestations, such as pallor, failure to thrive, developmental delay, weakness, and irritability [2,3]. Hematological manifestations completely resolve following vitamin B12 supplementation, but neurologic findings may persist [4]; therefore, early diagnosis and treatment are important. Herein we present 45 children treated for various symptoms of vitamin B12 deficiency, and their long-term clinical and laboratory outcomes.

\section{Materials and Methods}

Clinical and laboratory findings in 45 children treated for vitamin B12 deficiency between January 1996 and December 2009 were retrospectively evaluated. Symptoms and physical findings, and percentiles for weight, height, and head circumference at presentation were recorded. The level of educational of the patients' mothers, vitamin B12 deficiency-related diseases, and family income data were collected. Daily intake of vitamin B12 and folate in the patients and their breast-feeding mothers were evaluated based on reports of their diets during the previous week [5]. Growth retardation (short height and low weight) were defined as below the third percentile.

Complete blood count, serum vitamin B12, folate, iron, iron binding capacity and ferritin, and plasma homocysteine levels were recorded measured at presentation. Vitamin B12 absorption testing could not be performed in any of the patients. Routine urinary analysis was performed to test for proteinuria. Anemia, thrombocytopenia, and leukopenia were defined as follows: hemoglobin level $<12 \mathrm{~g} / \mathrm{dL}$, thrombocyte level $<150,000 \mathrm{~mm}$, and leukocyte count $<4500 \mathrm{~mm}$, respectively. Low-level vitamin $\mathrm{B} 12$, folate, and ferritin was accepted as $200 \mathrm{pg} / \mathrm{mL}$, $3 \mathrm{ng} / \mathrm{mL}$, and $20 \mathrm{pg} / \mathrm{mL}$, respectively. Plasma homocysteine levels $>12 \mathrm{~g} / \mathrm{dL}$ were considered as high. Peripheral blood smear screening for macrocytosis and hypersegmentation was performed. Hemoglobin electrophoresis was used to rule out the thalassemia trait in children with an MCV $<85 \mathrm{fL}$.

The patients were treated with vitamin B12, as follows: $1 \mathrm{mg} / \mathrm{d}$ IM for 1 week, followed by $1 \mathrm{mg}$ IM QWK for 2 weeks, and then monthly $1 \mathrm{mg}$ injec- 
tions. Iron supplementation of $6 \mathrm{mg} \mathrm{kg} / \mathrm{d}$ was given to the patients with iron deficiency. Complete blood count, serum vitamin B12, folate, and plasma homocysteine were measured after 1 and 6 months of treatment. Neuromotor development in the patients was re-evaluated using the Denver II Development Screening Test 1 year after treatment started. Visual evoked potential (VEP) and brain stem evoked potential (BAEP) response testing were performed to determine the integrity and function of the visual pathway, and auditory function, respectively.

Statistical calculations were performed using SPSS for Windows v.16.0. Normal distribution was tested using the Shapiro-Wilk test. The MannWhitney U test was used to compare the iron deficient patients and those without iron deficiency. The Wilcoxon test was used to compare pre- and post-treatment findings. The chi-square test was used for categorical variables. Statistical significance was accepted as $\mathrm{p}<0.05$. The study protocol was approved by the Uludağ University Ethics Committee.

\section{Results}

Mean age at presentation of the 20 male and 25 female patients was 5.6 5.9 years (range: 1.4 months-17 years). Mean follow-up was 46 \pm 36 months (range: 10-150 months). The most common symptoms were weakness, failure to thrive, and hematologic manifestations (pallor, petechiae, ecchymosis)., followed by gastrointestinal and neurologic symptoms (Table 1). Both the patients and their breast-feeding mothers had low dietary intake of vitamin B12. (Among the 22 patients aged $<2$ years, 19 were breastfed and/or had supplementary food. The rest $(n=3)$ were on normal diet. Only one patient in our case series (older than 2 years) was on special diet for phenylketonuria. Proteinuria was associated in $4(8.8 \%)$ out of 45 patients and their ages ranged from 1 to 6 years (mean: 3.6 \pm 2.4 years). In addition, 6 (13.3\%) out of 45 patients had vitamin B12 deficiency-related diseases, including cerebral palsy (CP) $(n=2)$, short gut syndrome $(n=1)$, operated duodenal atresia $(n=1)$, celiac disease $(n=1)$, and phenylketonuria $(n=1)$. They were older than 2 years.

Only $15 \%$ of the patients' mothers had a level of education above primary school. In all, $80 \%(n=36)$ of the patients' families had a monthly income pro- viding the threshold, as defined in a recent report by the Turkish Statistical Institute [6].

In all, $10(22 \%)$ of the patients had height and weight below the $3^{\text {rd }}$ percentile at presentation, of which only 2 had a comorbid disease (CP); height and weight in the 8 children without a comorbid disease were normal ( $>3^{\text {rd }}$ percentile) after receiving treatment for 1 year. Serum B12, folate, and plasma homocysteine levels are shown in the Figure 1. In all, 8 patients (19\%) had serum B12 and folate levels

Table 1. Patients' Symptoms and Physical Findings at Presentation

\begin{tabular}{lcc}
\hline & $\begin{array}{c}\text { Symptoms } \\
\text { (<2 years/ } \\
\geq \mathbf{2} \text { years) }\end{array}$ & $\begin{array}{c}\text { Physical Findings } \\
\text { (<2 years/ } \\
\geq \mathbf{2} \text { years) }\end{array}$ \\
\hline General (Total) & $31(69 \%)$ & $10(22 \%)$ \\
Weakness & $5 / 19$ & - \\
Failure to thrive & $5 / 2$ & $5 / 5$ \\
Hematologic (Total) & $23(51 \%)$ & $42(93 \%)$ \\
Pallor & $10 / 6$ & $20 / 18$ \\
Petechiae-Ecchymosis & $4 / 3$ & $3 / 1$ \\
Gastrointestinal (Total) & $12(27 \%)$ & $9(20 \%)$ \\
Oral ulcer & $2 / 2$ & $2 / 2$ \\
Vomiting & $4 / 1$ & - \\
Pain on abdomen & $1 / 2$ & - \\
Hepatosplenomegaly & - & $3 / 2$ \\
Neurologic (Total) & $8(18 \%)$ & $9(20 \%)$ \\
Seizure & $4 /$ None & - \\
Paresthesia on legs & None/1 & - \\
No head control/no walking & $3 /$ None & - \\
Neuromotor retardation & - & $3 /$ None* \\
Hypotonia & - & $4 /$ None \\
Microcephaly & - & $1 / 1$ \\
\hline
\end{tabular}

*Patients with CP $(n=2)$ were excluded

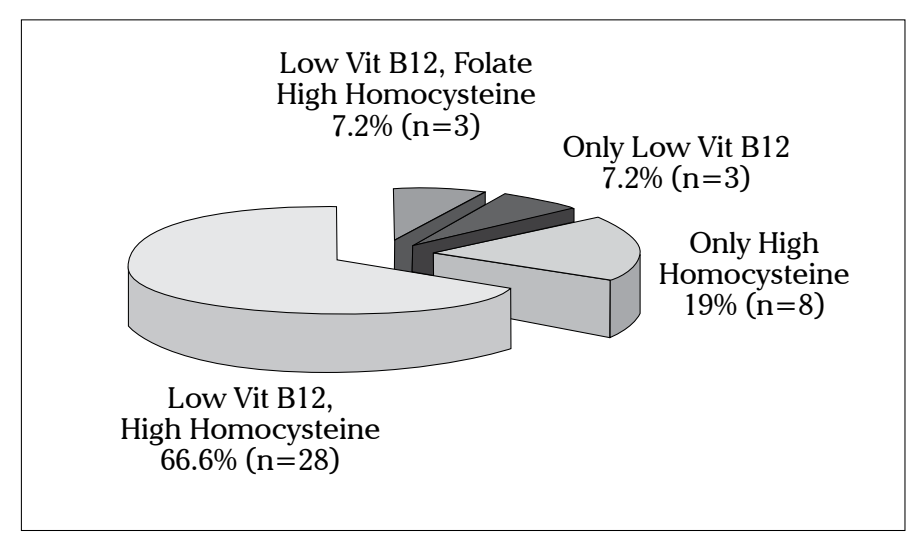

Figure 1. Distribution of Patients According to Serum B12, Folate, and Plasma Homocysteine Levels

*The results of transfused patients $(n=3)$ were excluded 
within the normal range; however, their plasma homocysteine levels were high. The serum vitamin B12 level was low in $15(79 \%)$ of the 19 breastfeeding mothers.

Of all the patients $(n=45), 20(44 \%)$ had only anemia, whereas $12(27 \%)$ had bicytopenia and 10 $(22 \%)$ had pancytopenia. In all, 3 patients had a normal hemoglobin level due to recent erythrocyte transfusion and their hematologic and serologic findings were excluded from the study's analysis. In total, 8 out of 45 patient (19\%) had iron deficiency anemia and normal hemoglobin electrophoresis findings; none of these 8 patients had another comorbid disease or neurologic symptoms at presentation. Hematologic findings in the patients are shown in Table 2.

Hematologic findings in all the patients improved significantly after the $1^{\text {st }}$ and $6^{\text {th }}$ months of treatment (Table 3); however, patients without iron deficiency had significantly greater hematologic recovery after the $1^{\text {st }}$ month of treatment than the iron-deficient patients (Table 4).

Abnormal neurologic findings at presentation were observed in $9(20 \%)$ of the patients. Cases with $\mathrm{CP}$ were excluded from this data since it is difficult to make a definitive distinction of their neurologic findings. None of the 9 patients had iron deficiency anemia. I Eight of these children were younger than 2 years old (Table 1). Additionally, 4 of these 8 children presented with convulsions and were successfully treated with vitamin B12 and anticonvulsants. Neuromotor retardation and hypotonia were observed in 7 patients and all had a good response to vitamin B12 treatment. All 8 patients aged $<2$ years with abnormal neurologic findings underwent cranial MRI; cerebral atrophy and secondary external hydrocephaly were observed in 5 of them.

Table 2. Patients' Hematologic Findings at the Time of Presentation, According to Iron Status

\begin{tabular}{lccc}
\hline & $\begin{array}{c}\text { Patients with Iron Deficiency } \\
\mathbf{n = 8}(\mathbf{1 9 \% )}\end{array}$ & $\begin{array}{c}\text { Patients without Iron Deficiency } \\
\mathbf{n = 3 4}(\mathbf{8 1 \% )}\end{array}$ & p \\
\hline Female/Male & $3 / 5$ & $18 / 16$ & $>0.05$ \\
Age (years) & $3.7(0.33-17)$ & $1.45(0.12-16)$ & $>0.05$ \\
Hemoglobin (g/dL) & $7.2(4.5-8.7)$ & $7.7(4.3-12)$ & $>0.05$ \\
MCV (fL) & $78.1(59.5-80)$ & $98.2(83-114)$ & $<0.001$ \\
Leukocyte $\left(\mathrm{mm}^{3}\right)$ & $8650(2400-17200)$ & $5565(1100-19000)$ & $>0.05$ \\
Thrombocyte (mm $\left.{ }^{3}\right)$ & $111,000(158.00-380.000)$ & $195,000(43.000-401.000)$ & $>0.05$ \\
Vitamin B12 (pg/mL) & $115(34-1000)$ & $150(31-755)$ & $>0.05$ \\
Folate (ng/mL) & $6.2(3.2-22.8)$ & $15(1.1-27)$ & $<0.05$ \\
Homocysteine (g/dL) & $12.3(6.9-68.6)$ & $19.5(2-106)$ & $>0.05$ \\
Ferritin (pg/mL) & $7(3-13)$ & $39.5(18-848)$ & $<0.001$ \\
Growth Retardation & $4(50 \%)$ & $6(17.6 \%)$ & 0.075 \\
\hline
\end{tabular}

Values were given as median (range), *The results of transfused patients $(n=3)$ were excluded

Table 3. Patients' Hematologic Findings at Diagnosis, and After 1 and 6 Months of Treatment

\begin{tabular}{|c|c|c|c|c|c|}
\hline Time & $\begin{array}{l}\mathrm{Hb} \pm \mathrm{S} \\
\text { (range) }\end{array}$ & $\begin{array}{c}\mathrm{MCV} \pm \mathrm{SD} \\
\text { (range) }\end{array}$ & $\begin{array}{c}\text { Vitamin B12 } \pm \mathrm{SD} \\
\text { (range) }\end{array}$ & $\begin{array}{c}\text { Folate } \pm \text { SD } \\
\text { (range) }\end{array}$ & $\begin{array}{l}\mathrm{H} \pm \mathrm{SD} \\
\text { (range) }\end{array}$ \\
\hline Admission & $\begin{array}{c}8.1 \pm 2.7 \\
(4.3-15.5)\end{array}$ & $\begin{array}{l}93.2 \pm 12.8 \\
(59.5-115)\end{array}$ & $\begin{array}{c}206.6 \pm 185.6 \\
(31-1000)\end{array}$ & $\begin{array}{c}13.1 \pm 7.6 \\
(1.1-27)\end{array}$ & $\begin{array}{c}26.4 \pm 23.3 \\
(2-106)\end{array}$ \\
\hline 1 month & $\begin{array}{c}12.3 \pm 2.4 \\
(10.1-14.5)\end{array}$ & $\begin{array}{c}90 \pm 5 \\
(85-96)\end{array}$ & $\begin{array}{l}400 \pm 150 \\
(243-568)\end{array}$ & $\begin{array}{c}15.2 \pm 6.1 \\
(8-22)\end{array}$ & $\begin{array}{c}10.4 \pm 6.3 \\
(4-18)\end{array}$ \\
\hline 6 month & $\begin{array}{c}14.6 \pm 2.2 \\
(12.1-15.9)\end{array}$ & $\begin{array}{c}88 \pm 4 \\
(84-93)\end{array}$ & $\begin{array}{l}800 \pm 100 \\
(678-942)\end{array}$ & $\begin{array}{c}16.3 \pm 4.2 \\
(11-25)\end{array}$ & $\begin{array}{c}6.1 \pm 2.3 \\
(4-9)\end{array}$ \\
\hline $\mathrm{Pa}$ & $<0.001$ & $<0.001$ & $<0.001$ & $>0.05$ & $<0.001$ \\
\hline $\mathrm{Pb}$ & $<0.001$ & $<0.001$ & $<0.001$ & $>0.05$ & $<0.001$ \\
\hline
\end{tabular}

Pa: Presentation and $1^{\text {st }}$ month of treatment; Pb: presentation and $6^{\text {th }}$ month of treatment, SD: Standard deviation; H: homocysteine 
Table 4. Treatment Response of the Patients, According to İron Status*

\begin{tabular}{|c|c|c|c|c|c|c|}
\hline & \multicolumn{3}{|c|}{$\begin{array}{l}\text { Patients with Iron Deficiency } \\
\qquad n=8\end{array}$} & \multicolumn{3}{|c|}{$\begin{array}{l}\text { Patients without Iron Deficiency } \\
\qquad \mathrm{n}=34\end{array}$} \\
\hline $\mathrm{Hb}(\mathrm{g} / \mathrm{dL})$ & 7.2 & 9.2 & $<0.05$ & 7.7 & 11.1 & $<0.001$ \\
\hline $\operatorname{MCV}(\mathrm{fL})$ & 78.1 & 82 & $>0.05$ & 98.2 & 87 & $<0.001$ \\
\hline Vitamin B12 (pg/mL) & 115 & 565 & $<0.05$ & 150 & 482 & $<0.001$ \\
\hline Folate $(\mathrm{ng} / \mathrm{mL})$ & 6.2 & 14 & $>0.05$ & 15 & 19.5 & $>0.05$ \\
\hline
\end{tabular}

Values are given as median, TP1: At presentation; TP2: after 1 month of treatment, *The results of transfused patients (n=3) were excluded

During vitamin B12 treatment 4 patients developed myoclonus and tremors; these involuntary movements resolved in 2 patients with clonazepam, whereas piracetam was added to the treatment in the other 2 patients Involuntary movements in them resolved as well. VEP, BAEP, and Denver II Development tests were performed in $30(66 \%)$ of the patients between treatment months 9 and 15 (mean: $11.9 \pm 1.88$ months). VEP and BAEP intervals were prolonged in $11(37 \%)$ and $5(17 \%)$ of the patients, respectively. Denver II Development Test results showed developmental delay in $6(20 \%)$ of the patients (Table 5).

\section{Discussion}

The most common manifestations of vitamin B12 deficiency observed in the present study were weakness and failure to thrive. Hematologic, gastrointestinal, and neurologic symptoms were observed in $51 \%, 27 \%$, and $18 \%$ of the patients, respectively. Poor dietary intake is reported to be the most common cause of vitamin B12 deficiency [1]; however, Altay et al. had reported a series containing 36 children from Turkey with selective vitamin B12 malabsorption [7]. Unfortunately, we were unable to perform absorption tests in the present study. The necessity of using radioactively labeled compounds makes these tests extremely difficult to perform [8]. An alternative approach for evaluating vitamin B12 absorption is measurement of vitamin B12 saturated-transcobalamin (holo-TC) [9]. Bor et al. [10] reported that the diagnostic sensitivity and specificity of holo-TC measurement was $100 \%$ and $92 \%$, respectively. In the present study only $4(8.8 \%)$ patients $<6$ years of age had proteinuria; as vitamin B12 absorption testing was not available, we could only assume that these 4 patients might have had
Table 5. VEP, BAEP, and Denver II Findings

\begin{tabular}{cccc}
\hline \multicolumn{1}{c}{$\mathbf{n}=\mathbf{3 0}$} & VEP & BAEP & Denver II \\
\hline Abnormal & $11(37 \%)$ & $5(17 \%)$ & $6(20 \%)$ \\
Normal & $19(63 \%)$ & $25(83 \%)$ & $24(80 \%)$ \\
\hline
\end{tabular}

*Patients with $\mathrm{CP}(\mathrm{n}=2)$ were excluded

Imerslund-Gräsbeck syndrome. Altay et al. [7] observed proteinuria in $78 \%$ of children with Imerslund-Gräsbeck syndrome, all of who were younger than those without proteinuria. All of the patients with proteinuria in the present study were $<6$ years old. All of the patients in the present study and their breast-feeding mothers had low dietary intake of vitamin B12 and 79\% of the breast-feeding mothers had low-level serum B12. Based on the present study's data, we think that poor dietary intake resulted in the observed vitamin B12 deficiency.

Consumption of meat and dairy products in Turkey has decreased during the last 2 decades due to economic crisis [11] and is lower than that in developed countries [12]. In fact, in the present study, $80 \%$ of the patients' families were in low socioeconomic status. The incidence of vitamin B12 deficiency in Turkish pregnant women ranges from $48.8 \%$ to $80.9 \%$ [13,14]. Koc et al. [15] reported that the incidence of vitamin B12 deficiency in Turkish infants and their mothers was $72 \%$ and $41 \%$, respectively. Based on such data, vitamin B12 deficiency is an important problem in Turkey and infants born to deficient mothers are at high risk for developing manifestations of vitamin B12 deficiency. Therefore, nutritional and educational programs are required in Turkey, especially for pregnant and lactating women.

Hematologic findings in patients with vitamin B12 deficiency vary from anemia to pancytopenia [16]. Macrocytosis is not a common finding. MCV does 
not increase when vitamin B12 deficiency is associated with iron deficiency or the thalassemia trait $[16,17]$. Although none of the patients in the present study had the thalassemia trait, Sayli et al. [18] reported Imerslund-Gräsbeck syndrome coexisting with the beta-thalassemia trait in a Turkish study population. In the present study $44 \%$ of the patients had only anemia, whereas $27 \%$ had bicytopenia, and $22 \%$ had pancytopenia, which resolved after 1 and 6 months of treatment, respectively $(\mathrm{p}<0.001)$. Additionally, 8 (19\%) of the patients also had iron deficiency anemia, with an MCV $<85 \mathrm{fL}$. The diagnosis of vitamin B12 deficiency is based on lowlevel serum vitamin B12 (usually $<200 \mathrm{pg} / \mathrm{mL}$ ), along with clinical evidence of disease [18]. In the present study $81 \%$ of the patients had low-level serum vitamin B12; however, it has been reported that patients with clinical signs of vitamin B12 deficiency can have a normal serum vitamin B12 level $[19,20]$. A study that included 406 patients with vitamin B12 deficiency reported that $98.4 \%$ had elevated serum methylmalonic acid (MMA) and 95.9\% had elevated serum homocysteine [21]. Other reports suggest that the sensitivity and specificity of the serum B12 assay are significantly lower than previously thought [20,22-25]. We were unable to measure serum MMA in the present study; however, plasma homocysteine was high in $91 \%$ of the patients. In addition, the diagnosis of vitamin B12 deficiency was confirmed in 8 (19\%) of the patients based only on a high plasma homocysteine level.

In the present study more patients $<2$ years of age presented with neurologic symptoms than those aged $\geq 2$ years $(p<0.05)$. Numerous case reports have reported neurologic symptoms in patients with vitamin B12 deficiency in infants [26-30] and 2 large series from Turkey reported various neurologic symptoms in infants [31,32]. These findings might be due to the fact that myelinization of the central nervous system is incomplete and ongoing during the first 2 years of life. Although the mechanism of neurologic symptoms in B12 deficiency is not fully known, delayed myelination, neurotrophic and neurotoxic cytokine imbalance, and accumulation of lactate in brain cells have been proposed [33]. Seizure was the first symptom of vitamin B12 deficiency in 4 (9\%) of the present study's patients; their EEGs were dysrhythmic with epileptic abnormalities. Several studies reported an association between vitamin B12 deficiency and EEG abnormalities [34]. Cranial MRI in 5 of the present study's 8 patients aged $<2$ years that presented with abnormal neurologic findings showed cerebral atrophy. Cortical atrophy, thinning of the corpus callosum, and retarded myelination have been reported as neuroradiological imaging findings in patients with vitamin B12 deficiency [35,36]. In the present study 4 patients developed involuntary movements during vitamin B12 treatment; it has been reported that such movements rarely occur during vitamin B12 treatment [37,38], although its mechanism is not fully known.

The patients in the present study recovered in response to vitamin B12 treatment from the following symptoms: pallor, petechiae, ecchymosis, failure to thrive, anorexia, vomiting, hypotonia, apathy, seizures, and neuromotor retardation. Hematologic indices and biochemical parameters returned to normal shortly after the start of vitamin B12 treatment; however, the patients with iron deficiency had slow improvement than those without iron deficiency $(\mathrm{p}<0.05, \mathrm{p}<0.001$ respectively), even though their initial hemoglobin and serum vitamin B12 levels were similar (Table 4). We think that welldesigned controlled studies with large patient populations could yield valuable data concerning the relationship between vitamin B12 deficiency and iron deficiency.

In the present study VEP and BAEP intervals were prolonged and Denver II Development Test results showed developmental delay in 33\% of the patients after 12 months of treatment. Although we were not able to perform these tests prior to treatment, we think these abnormalities were the result of vitamin B12 deficiency, as there were no other obvious disorders that could explain the findings. Abnormal VEP results were previously reported in cobalamin deficiency [39]. Despite dramatic hematologic and clinical improvement following vitamin B12 treatment, pediatric patients may suffer cognitive and developmental retardation [4]. The longterm prognosis of vitamin B12 deficiency depends on the severity and duration of deficiency. Delayed diagnosis (made after 1 year of age) is associated with permanent neurologic abnormality [40,41].

In conclusion, in the present study neurologic manifestations of vitamin B12 deficiency occurred in more of the patients aged $<2$ years than in those 
aged $\geq 2$ years. In the long-term outcome, patients ranged from $17 \%$ to $37 \%$ tested for neurologic abnormalities had persistent developmental and myelination delays. As such, clinicians must followup pediatric patients with vitamin B12 deficiency after hematologic and clinical improvements are observed in order to assess their neurologic status.

\section{Conflict of interest statement}

The authors of this paper have no conflicts of interest, including specific financial interests, relationships, and/or affiliations relevant to the subject matter or materials included.

\section{References}

1. Stabler SP, Allen RH. Vitamin B12 deficiency as a worldwide problem. Annu Rev Nutr 2004;24:299-326. [CrossRef]

2. Rasmussen SA, Fernhoff PM, Scanlon KS. Vitamin B12 deficieny children and adolecents. J Pediatr 2001;138:10-7. [CrossRef]

3. Goraya JS. Vitamin B12 deficiency in childhood and adolescence. J Pediatr 2002;140:636. [CrossRef]

4. Graham SM, Arvela OM, Wise GA. Long-term neurological consequences of nutritional VB12 deficiency in infants. J Pediatr 1992;121:710-4. [CrossRef]

5. Baysal A. Beslenme. Folik asit ve B12. 4.baskı. Ankara: Hacettepe yayınları;1983. 199-205.

6. Ensari S. Türkiye İstatistik Kurumunun Yoksulluk Analizleri Üzerine. Maliye Finans Yazıları 2010;87:9-15.

7. Altay C, Cetin M, Gümrük F, Irken G, Yetgin S, Laleli Y. Familial selective vitamin B12 malabsorption (Imerslund-Gräsbeck syndrome) in a pool of Turkish patients. Pediatr Hematol Oncol 1995;12:19-28. [CrossRef]

8. Schilling RF. Intrinsic factor studies II. The effect of gastric juice on the urinary excretion of radioactivity after the oral administration of radioactive vitamin B12. J Lab Clin Med 1953;42:860-6.

9. Bor MV, Nexø E, Hvas AM. Holo-transcobalamin concentration and transcobalamin saturation reflect recent vitamin B12 absorption better than does serum vitamin B12. Clin Chem 2004;50:1043-9. [CrossRef]

10. Bor MV, Cetin M, Aytaç S, Altay C, Nexo E. Nonradioactive vitamin B12 absorption test evaluated in controls and in patients with inherited malabsorption of vitamin B12. Clin Chem 2005;51:2151-5. [CrossRef]

11. Sarigedik U. Turkey livestock and products annual. USDA Foreign Agricultural Service GAIN Report. 2006;5:55-7.

12. Koc A, Uzunlu V, Bayaner A. Turkish agricultural projection 2000-2010. Agricultural Eco res Inst, Ministry Agriculture Rural Affairs. 2001;1:34.

13. Ackurt F, Wetherilt $\mathrm{H}$, Loker $\mathrm{M}$, Hacibekiroglu $\mathrm{M}$. Biochemical assessment of nutritional status in pre- and post-natal Turkish women and outcome of pregnancy. Eur J Clin Nutr 1995;49:613-22.

14. Harma M, Yurtseven Ş, Koç A Demir N. Şanlıurfa ilinde gebe kadınların $\mathrm{B} 12$ ve folik asit serum düzeyleri. Jinekoloji ve Obstetrik Dergisi. 2003;17:212-7.

15. Koc A, Kocyigit A, Soran M, Demir N, Sevinc E, Erel O, Mil Z. High frequency of maternal vitamin B12 deficiency as an important cause of infantile vitamin B12 deficiency in Sanliurfa Province of Turkey. Eur J Nutr 2006;45:291-7. [CrossRef]

16. Andrès E, Affenberger S, Zimmer J, Vinzio S, Grosu D, Pistol G, Maloisel F, Weitten T, Kaltenbach G, Blicklé JF. Current hematological findings in cobalamin deficiency. A study of 201 consecutive patients with documented cobalamin deficiency. Clin Lab Haematol 2006;28:50-6. [CrossRef]

17. Bay A, Öner AF, Nalbantoğlu Ö, Demirtaş M, Açıkgöz M. Megaloblastik anemili 45 olgunun klinik ve hematolojik yönden değerlendirilmesi. Van Tıp Dergisi 2006;13:46-8.

18. Saylı TR, Başak AN, Gümrük F, Gürgey A, Altay C. Imerslund-Gräsbeck syndrome coexisting with betathalassemia trait. Pediatr Hematol Oncol 1994;11:223-5. [CrossRef]

19. Wickramasinghe N. Diagnosis of megaloblastic anaemias. Blood Reviews 2006;20:299-318. [CrossRef]

20. Lindenbaum J, Savage DG, Stabler SP, Allen RH. Diagnosis of cobalamin deficiency: II. Relative sensitivities of serum cobalamin, methylmalonic acid, and total homocysteine concentrations. Am J Hematol 1990;34:99-107. [CrossRef]

21. Savage DG, Lindenbaum J, Stabler SP, Allen RH. Sensitivity of serum methylmalonic acid and total homocysteine derterminations for diagnosing cobalamin and folate deficiencies. Am J Med 1994;96:239-46. [CrossRef]

22. Healton EB, Savage DG, Brust JC, Garrett TJ, Lindenbaum J. Neurologic aspects of cobalamin deficiency. Medicine (Baltimore) 1991;70:229-45. [CrossRef]

23. Lindenbaum J, Healton EB, Savage DG, Brust JC, Garrett TJ, Podell ER, Marcell PD, Stabler SP, Allen RH. Neuropsychiatric disorders caused by cobalamin deficiency in the absence of anemia or macrocytosis. $\mathrm{N}$ Engl J Med 1988;318:1720-8. [CrossRef]

24. Metz J, Bell AH, Flicker L, Bottiglieri T, Ibrahim J, Seal E, Schultz D, Savoia H, McGrath KM. The significance of subnormal serum vitamin B12 concentration in older people: a case control study. J Am Geriatr Soc 1996;44:1355-61.

25. Stabler SP, Allen RH, Savage DG, Lindenbaum J. Clinical spectrum and diagnosis of cobalamin deficiency. Blood 1990;76:871-81.

26. Chalouhi C, Faesch S, Anthonie-Milhomme MC, Fulla Y, Dulac O, Cheron G. Neurological concequences of vitamin B12 deficiency and its treatment. Pediatr Emerg Care 2008;24:538-41. [CrossRef]

27. Weis R, Fogelman Y, Bennett M. Severe B12 deficiency in an infant associated with a maternal deficiency and a strict vegetarian diet. J Padiatr Hematol Oncol 2004;26:270-1. [CrossRef] 
28. Casella EB, Valente M, de Navarro JM, Kok F. Vitamin B12 deficiency in infancy as a cause of developmental regression. Brain Dev 2005;27:592-4. [CrossRef]

29. Garewal G, Narang A, Das KC. Infantile tremor syndrome: a vitamin B12 deficiency syndrome in infants. $\mathrm{J}$ Trop Pediatr 1988;34:174-8.

30. Kalayci O, Cetin M, Kirel B, Ozdirim E, Yetgin S, Aysun S, Gurgey A. Neurologic findings of vitamin B12 deficiency: presentation of 7 cases. Turk $\mathrm{J}$ Pediatr 1996;38:67-72.

31. Zengin E, Sarper N, Caki Kiliç S. Clinical manifestations of infants with nutritional vitamin B deficiency due to maternal dietary deficiency. Acta Paediatr 2009;98: 98-102. [CrossRef]

32. Incecik F, Hergüner MO, Altunbaşak S, Leblebisatan G. Neurologic findings of nutritional vitamin B12 deficiency in children.Turk J Pediatr 2010;52:17-21.

33. Dror DK, Allen LH. Effect of vitamin B12 deficiency on neurodevelopment in infants: current knowledge and possible mechanisms. Nutr Rev 2008;66:250-5. [CrossRef]

34. Biancheri R, Cerone R, Rossi A, Schiaffino MC, Caruso U, Minniti G, Perrone MV, Tortori-Donati P, Veneselli E. Early-onset cobalamin C/D deficiency: epilepsy and electroencephalographic features. Epilepsia 2002;43:616-22. [CrossRef]
35. Biancheri R, Cerone R, Schiaffino MC, Caruso U, Veneselli E, Perone MV, Rossi A, Gatti R. Cobalamin (Cbl) C/D deficiency: clinical, neurophysiological and neuroradiologic findings in 14 cases. Neuropediatrics 2001;32:14-22. [CrossRef]

36. Rossi A, Cerone R, Biancheri R, Gatti R, Schiaffino MC, Fonda C, Zammarchi E, Tortori-Donati P. Early-onset combined methylmalonic aciduria and homocystinuria: neuroradiologic findings. AJNR Am J Neuroradiol 2001;22:554-63.

37. Benbir G, Uysal S, Saltik S, Zeybek CA, Aydın A, Dervent A, Yalcınkaya C. Seizures during treatment of Vitamin B 12 deficiency. Seizure 2007;16:69-73. [CrossRef]

38. Ozdemir O, Baytan B, Gunes AM, Okan M. Involuntary movements during vitamin B12 treatment. J Child Neurol 2010;25:227-30. [CrossRef]

39. Krumholz A, Weiss HD, Goldstein PJ, Harris KC. Evoked responses in vitamin B12 deficiency. Ann Neurol 1981;9:407-9. [CrossRef]

40. von Schenck U, Bender-Götze C, Koletzko B. Persistence of neurological damage induced by dietary vitamin B-12 deficiency in infancy. Arch Dis Child 1997;77:137-9. [CrossRef]

41. Pearson AG, Turner AJ. Folate-dependent 1-carbon transfer to biogenic amines mediated by methylenetetrahydrofolate reductase. Nature 1975;258:173-4. [CrossRef] 